УДК 631.52:575.162+631.6+630

https://doi.org/10.32634/0869-8155-2021-344-1-110-112

Оригинальное исследование/Original research

Беляев А.И. ,

Зайцев В.Г.

Иващенко Р.Ю.,

Попова А.C.,

Агапова Д.А.

Старухина А.O.,

Желтова А.А.

Федеральный научный центр агроэкологии, комплексных мелиораций и защитного лесоразведения Российской академии наук. Россия, 400062, г. Волгоград, Университетский проспект, 97.

zaitsev@vfanc.ru, ivachenko-ru@vfanc.ru, popova-a@vfanc.ru,kurkina-d@vfanc.ru, staruhina-ao@vfanc.ru,zheltova-a@vfanc.ru

Ключевые слова: устойчивое земледелие агролесобиоценозы; молекулярные маркеры; маркер-ассоциированная селекция; пищевые культуры; биологические активные вещества

Для цитирования: Беляев А.И. Зайцев В.Г., Иващенко Р.Ю., Попова А.С. Агапова Д.А., Старухина А.О.,

Желтова А.А. Применение молекулярных маркеров для комплексного улучшения агролесобиоценозов в целях развития устойчивого земледелия. Аграрная наука. $2021 ; 344$ (1): 110-112.

https://doi.org/10.32634/0869-8155-2021-344-1-110-112

Конфликт интересов отсутствует

Alexander I. Belyaev,

Valery G. Zaitsev,

Regina Yu. Ivaschenko,

Anna S. Popova

Daria A. Agapova,

Anna 0. Starukhina,

Anastasia A. Zheltova

Federal Scientific Center of Agroecology, Integrated Land Reclamation and Protective Afforestation of the Russian Academy of Sciences.

Russia, 400062, Volgograd, Universitetsky prospect, 97.

zaitsev@vfanc.ru, ivachenko-ru@vfanc.ru popova-a@vfanc.ru,kurkina-d@vfanc.ru, staruhina-ao@vfanc.ru, zheltova-a@vfanc.ru

Key words: sustainable agriculture; agrolesobiocenoses; molecular markers; marker-associated selection; food crops; biological active substances

For citation: Belyaev A.I., Zaitsev V.G. Ivaschenko R.Yu., Popova A.S., Agapova D.A., Starukhina A.O., Zheltova A.A. Application of molecular markers for the comprehensive improvement of agro-forestry communities for the development of sustainable agriculture. Agrarian Science. 2021; 344 (1): 110-112. (In Russ.)

https://doi.org/10.32634/0869-8155-2021-344-1-110-112

There is no conflict of interests
Применение молекулярных

маркеров для комплексного

улучшения агролесобиоценозов

в целях развития устойчивого

земледелия

PE3ЮME

Актуальность и методика. Проведен анализ современного положения и перспектив использования молекулярных (ДНК) маркеров в современном растениеводстве и лесомелиорации.

Результаты. Показано, что применение молекулярных маркеров перспективно для отбора и выведения культур с повышенным синтезом метаболитов с доказанной пользой для здоровья человека. Для улучшения древесных пород молекулярные маркеры все еще почти не применяются. Комплексное использование молекулярных маркеров при скрининге и селекции сортов и форм пищевых сельскохозяйственных культур и древесных растений может позволить в короткие сроки повысить устойчивость и продуктивность лесоагробиоценозов.

\title{
Application of molecular markers for the comprehensive improvement of agro-forestry communities for the development of sustainable agriculture
}

\section{ABSTRACT}

Relevance and methods. Analysis of state-of-the-art and perspectives in use of molecular (DNA-based) markers in current horticulture and agroforestry was performed.

Results. We showed use of molecular markers for screening of crop varieties with elevated synthesis of human health beneficial metabolites. Molecular markers have not been used to improve varieties of trees yet. Complex use of molecular markers for variety screening and breeding of food crops and forest trees could improve sustainability and productivity of agroforestry systems.

Поступила: 3 ноября

После доработки: 11 января

Принята к публикации: 11 января
Received: 3 november

Revised: 11 january

Accepted: 11 january 


\section{Введение}

Прогрессирующий рост населения Земли в XXI веке происходит на фоне ухудшения качества земель сельскохозяйственного назначения, в частности, за счет аридизации многих регионов. Традиционные подходы экстенсивного земледелия практически достигли потолка своих возможностей. Новые перспективы связаны с развитием интенсивного устойчивого земледелия, которое может позволить получать высокие урожаи агропродукции хорошего качества с минимально возможным влиянием со стороны погодных условий, фитопатогенов и вредителей [1]. Развитие интенсивного устойчивого земледелия невозможно без создания новых сортов культурных растений, обладающих минимальной вариабельностью урожайности и качества продукции при изменении условий выращивания. Таким способом можно достигнуть устойчивых урожаев на некотором минимально гарантированном уровне при любых условиях окружающей среды.

Однако роста урожайности и повышения устойчивости пищевых культур может оказаться недостаточным для поддержания устойчивого уровня потребления населением полезных компонентов пищи. Увеличение содержания полезных для здоровья человека компонентов в пищевых растениях является альтернативной увеличению производства пищевых растений и способно улучшить общественное здоровье без существенного изменения пищевых привычек населения [2]. Тем не менее традиционные методы селекции с использованием т.н. классических маркеров достаточно долги и трудоемки и часто недостаточно эффективны. Альтернативой является использование молекулярных (ДНК) маркеров. Молекулярные маркеры представляют собой определенные последовательности ДНК с полиморфными вариантами у разных особей одного вида, связанные с различиями в их биологических особенностях Существует множество типов молекулярных маркеров в зависимости от особенностей выявляемых генетических различий и метода их детекции [3]. Взаимосвязь между биологическими свойствами и определенными маркерами позволяет использовать их для быстрого скрининга сортов (пород) растений и даже отдельных особей с наилучшим сочетанием целевых характеристик [4]. Отбор растений по молекулярным маркерам применяется в качестве первого этапа маркер-ассоци ированной селекции (marker-assisted selection - MAS), которая позволяет целенаправленно создавать желательные комбинации аллельных вариантов генов в новых культиварах, а значит, и улучшать целевой набор свойств у новых сортов [5]. Анализ молекулярных маркеров может помочь в скрининге и селекции сортов (пород) как в достижении классических целевых свойств (урожайность, устойчивость к неблагоприятным воздействиям), так и в повышении содержания полезных для здоровья человека метаболитов.

Ослабить влияние неблагоприятных факторов можно не только за счет повышения устойчивости культурных растений, но и за счет модификации окружающего биоценоза. Например, защитные лесополосы способны заметно улучшить микроклиматические условия и состав почвенных микроорганизмов, тем самым благоприятно воздействуя на локальные условия выращивания сельскохозяйственных культур [6]. Анализ молекулярных маркеров мог бы найти место в оптимизации растительного состава лесозащитных полос. Целью настоящей работы был анализ существующего состояния дел и перспектив использования молекулярных маркеров для комплексного улучшения компонентов агролесобиоценозов. Особое внимание уделено возможности улучшения пищевых культур с целью повышения их пользы для здоровья человека.

\section{Методика}

Первичный поиск публикаций осуществлялся с помощью международных баз данных и репозиториев научных публикаций Scopus, SpringerLink, PubMed, ScienceDirect. Поисковые запросы включали термины, характеризующие интересующие растения (конкретно и обобщенно) и их целевые признаки (свойства), например, устойчивость или содержание определенных метаболитов. В случае содержания полезных для здоровья соединений первично найденные статьи затем курировались вручную, для окончательного анализа использовались только работы, содержащие достоверно установленные корреляции между молекулярными маркерами и соответствующим свойством. Примеры поисковых запросов и список публикаций о связи молекулярных маркеров с содержанием соединений с доказанной пользой для здоровья, отобранных для окончательного анализа, приведены в файле дополнительных материалов (https://doi.org/10.5281/zenodo.4190531). В остальных случаях анализировалось только количество найденных публикаций.

\section{Результаты}

На данный момент существует большое количество публикаций о связи молекулярных маркеров с какими-либо признаками у пищевых культурных растений. Так, при поиске результатов исследований по запросу "molecular marker" AND "crops" было обнаружено 4105 публикаций в Scopus. Не более $10 \%$ публикаций были связаны с устойчивостью к неблагоприятным климатическим факторам, включая 283 по устойчивости к засухе и 48 публикаций по устойчивости к засолению. Для ряда культур были выявлены ДНК-маркеры, ассоциированные с повышенной устойчивостью к высокой или низкой температуре, к избыточной или недостаточной инсоляции, а также с устойчивой урожайностью и сохранением качества продукции при выращивании в неблагоприятных экологических условиях.

Особый интерес представляет выявление комбинаций маркеров одного признака, как, например, комплекс 13 молекулярных маркеров устойчивости к засухе у пшеницы [7] или 52 маркера устойчивости к засолению почвы у ячменя [8]. В последнее десятилетие выросло число работ с использованием MAS при выведении новых сортов пищевых растений, включая зерновые культуры, например, пшеницу, ячмень, кукурузу [9], тем более, что MAS является финансово менее затратной, менее трудоемкой, более быстрой, чем классическая селекция [10]. Тем не менее Scopus содержит всего лишь 4 публикации по MAS пищевых растений на устойчивость к засолению и 25 - на устойчивость к засухе из 251 публикации по MAS пищевых растений.

Несмотря на перспективность использования молекулярных маркеров для скрининга существующих и выведения новых сортов пищевых культур, которые обладали бы повышенной продукцией биологически активных соединений с доказанной пользой для здоровья человека $[2,11]$, в рейтинговых журналах находится небольшое количество публикаций, содержащих информацию о молекулярных маркерах, ассоциированных с продукцией полезных для человека биологически активных соединений. В таблице суммирована инфор- 
Таблица 1. Количество молекулярных маркеров культивируемых пищевых растений, для которых установлена корреляция с содержанием соединений с доказанной пользой для здоровья человека

Table 1. Number of molecular markers in cultivated food plants that have been correlated with the content of compounds with proven health benefits

\begin{tabular}{|l|c|c|c|c|}
\hline \multicolumn{1}{|c|}{ Культура } & Цель поиска & Число статей & Число маркеров & Типы маркеров* \\
\hline $\begin{array}{l}\text { Kaпустные } \\
\text { (Brassicaceae) }\end{array}$ & Глюкозинолаты & 2 & 85 & QTL \\
\hline $\begin{array}{l}\text { Пнтоцианы } \\
\text { Посевной салат }\end{array}$ & Антоцианы & 4 & 11 & SNP \\
\hline $\begin{array}{l}\text { Lactuca sativa) } \\
\text { Каротиноиды }\end{array}$ & 1 & 19 & SNP, GWAS, QTL \\
\hline $\begin{array}{l}\text { Ячмень (Hordeum } \\
\text { vulgare) }\end{array}$ & Альфа-амилаза & 2 & 2 & QTL \\
\hline Тыква (Cucurbita) & Каротиноиды & 2 & 4 & QTL \\
\hline Рис (Oryza) & Антоцианы & 1 & 10 & SSR \\
\hline Виноград (Vitis) & Антоцианы & 2 & 25 & QTL \\
\hline
\end{tabular}

* типы молекулярных маркеров указываются в соответствии с номенклатурой, подробно рассмотренной в $[3,4]$.

мация о числе таких публикаций и описанных в них маркерах для ряда пищевых культур, выращиваемых в Европейской части РФ.

Исследования молекулярных маркеров у древесных пород, в том числе используемых в защитном лесоразведении, находятся на начальном этапе развития. В Scopus на октябрь 2020 года выявлено всего лишь 108 публикаций по запросу "molecular marker" AND "forest tree", из которых лишь 2 связаны с проблемой засухи. Для большинства из видов деревьев молекулярные маркеры были использованы исключительно для оценки биологического (генетического) разнообразия. Лишь для некоторых лесных культур, например, тополя, выявлен набор маркеров устойчивости к абиотическому стрессу [12], а успешные примеры использования MAS существуют только для отдельных видов (ольха, береза, вяз) [13].

\section{Выводы}

Подходы, связанные с использованием молекулярных маркеров, могут помочь в относительно короткое время заметно улучшить устойчивость и продуктивность лесоагробиоценозов. Основные перспективы связаны с маркер-ассоциированным скринингом и селекцией пищевых сельскохозяйственных культур. Усиленный синтез метаболитов с доказанной пользой для здоровья человека следует рассматривать как одну из важных целей выведения новых сортов пищевых культур. Практически неисследованной остается область маркер-ассоциированного скрининга и селекции деревьев и кустарников, которые могут быть использованы в защитном лесоразведении.

8. Mwando E., et al. Genome-Wide Association Study of Salinity Tolerance During Germination in Barley (Hordeum vulgare L.). Frontiers in Plant Science. 2020;(11):118.

9. Gantait S., Sarkar S., Verma S.K. Marker-assisted selection for abiotic Stress tolerance in crop plants. Molecular Plant Abiotic Stress: Biology and Biotechnology. 2019. https://doi. org/10.1002/9781119463665.ch18

10. Melese L. Marker Assisted Selection in Comparison to Conventional Plant Breeding: Review Article. Agri Res \& Tech: Open Access J. 2018;(14):555914.

11. Zaitsev V.G., et al. Toward Human Health-Promoting Food Plants: Perspectives of Marker-Assisted Breeding of AnthocyaninRich Lettuce. Eur. J. Mol. Biothechnol. 2019;7(1):40-46.

12. Wang B., et al. Identification of SSR loci from transcription factor genes expressed under abiotic stresses in poplar. Scientia Silvae Sinicae. 2011;47(8):67-74.

13. Pijut P. M., et al. Technological advances in temperate hardwood tree improvement including breeding and molecular marker applications. In Vitro Cellular and Developmental Biology - Plant. 2007;(43):283-303.

\section{ABOUT THE AUTHORS:}

Alexander I. Belyaev, Doctor of Agricultural Sciences, Director Valery G. Zaitsev, Candidate of Biological Sciences, Leading Researcher - Head of the Laboratory of Molecular Selection, zaitsev@vfanc.ru; https://orcid.org/0000-0001-9191-2862 Regina Yu. Ivaschenko, junior researcher; ivachenko-ru@vfanc.ru. Anna S. Popova, Junior Researcher, popova-a@vfanc.ru; http://orcid.org/0000-0002-5983-4080

Daria A. Agapova, Junior Researcher, kurkina-d@vfanc.ru Anna 0. Starukhina, junior researcher, staruhina-ao@vfanc.ru Anastasia A. Zheltova, Candidate of Medical Sciences, Leading Researcher, zheltova-a@vfanc.ru, https://orcid.org/0000-0002-8078-6407 